\title{
PONOWOCZESNY WYMIAR SUBKULTUR MŁODZIEŻOWYCH W ROSJI
}

\section{ABSTRACT A postmodern dimension of youth subcultures in Russia}

This paper aims to present contemporary characteristics of youth subcultures which result from the concept of postmodern era. With this end in view, in the introduction some selected research positions have been analysed for which the reference point is the theory of postmodernism and contemporary changes within the culture. In the first place, the characteristics of postmodern period have been put forward which help to describe macrosocial and microsocial structures such as fragmentation, a loss in continuity in terms of time and space, a negation of tradition and authority, the information chaos, a multitude of behaviour patterns as well as moral systems. The systematization of selective distinctive features of postmodernity made it possible to analyse changes within the contemporary cultural movements of the youth in the further part of this paper. To some very crucial characteristics of postsubculture belong: the precedence of personal identity of man over the collective one, political indifference, the heterogeneity of style, and the lack of being authentic and original.

The essential part of this study is to depict the Russian cultural specificity in relation to contemporary movements of the young having a cultural nature. The main presupposition is to treat the Russian subcultures as borrowed patterns the West through the process of "culture staging", for which the influence of the media and globalization is of great importance. On the other hand, changes in the contemporary environment of the young in Russia have been shown in such a way as to take into consideration the fact of dissimilarity arising from the eastern cultural impact and the domination of a monolithic culture in the period of the Soviet Union. Furthermore, the fact of the existence of the Russian "crisis awareness" in relation to social and political changes in the period of political system transformation has great weight. 
Keywords: youth subcultures, postsubcultures, postmodern, Russian youth culture

Słowa kluczowe: subkultury młodzieżowe, postsubkultury, ponowoczesność, rosyjska kultura młodzieżowa

\section{POJĘCIE PONOWOCZESNOŚCI}

Współczesne nauki humanistyczne, bez względu na przedmiot swych badań, nie mogą pozostać obojętne wobec terminu „ponowoczesność. I choć pojęcie ponowoczesności jest wciąż chwiejne i nieprecyzyjne, uwagę wielu badaczy zaprząta kierunek i charakter przemian we współczesnej kulturze i relacjach społecznych. Ponowoczesność bywa często utożsamiana z postmodernizmem, a oba terminy są używane zamiennie. Należy jednak podkreślić fakt, iż o ponowoczesności możemy mówić w kategoriach trwającej epoki, zakładającej idę̨ transformacji epoki poprzedniej - nowoczesności. Jest to dokonujące się na naszych oczach przejście do nowego okresu historycznego i nowych form społecznych. Postmodernizm to jeden z aspektów współczesnej kultury społeczeństwa ponowoczesnego, widoczny w wielu dziedzinach ludzkiej działalności. Mianem postmodernizmu określa się także stan ducha obecnych czasów (Jean François Lyotard), filozoficzny i estetyczny prąd bądź formację kulturową ${ }^{1}$. Znaczenie pojęciowe postmodernizmu jest niezwykle szerokie i wydaje się, że wciąż brak temu terminowi systematyzacji. Niemniej jednak aktualny stan badań pozwala wskazać na kilka dominujących cech ponowoczesności. Jedną z nich jest fragmentaryzacja, którą można zaobserwować na poziomie czasu i przestrzeni, stylu życia i osobowości. Poczucie czasu i przestrzeni zatraciło swój spójny charakter, ustępując miejsca zamieszaniu i zniekształceniu. Ciągłość i hierarchia zostały zastąpione siecią zjawisk, w której wielość i różnorodność wydają się nadrzędne w stosunku do układu liniowego. Współczesne możliwości komunikacyjne i technologiczne spowodowały stosunkową łatwość przemieszczania się ludzi i informacji, a czas i miejsce stały się mniej zrozumiałe i mało stabilne.

$\mathrm{Na}$ gruncie filozofii człowieka można mówić o osobowości niepewnej, fragmentarycznej i nieuporządkowanej, czego wykładnię znajdujemy w pracach Zygmunta Baumana. Filozof ten, kwestionując całość i spójność człowieka doby ponowoczesnej, opisał osobowość postmodernizmu jako zlepek czterech postaci: Spacerowicza, Gracza, Włóczęgi i Turysty². Istotnymi cechami tych antropologicznych wzorów, rzutującymi na relacje międzyludzkie, są: zmienność, epizodyczność, niekonsekwencja w działaniu, niestabilność, niechęć do angażowania się w jakąkolwiek działalność.

R. Geisler, Jednostka i spoteczeństwo w postmodernizmie, Częstochowa 1999, s. 35.

2 Z. Bauman, Dwa szkice o moralności ponowoczesnej, Warszawa 1994, Biblioteka Kultury Wspótczesnej. Zob. także: tenże, O turystach $i$ wtóczeggach, czyli o bohaterach i ofiarach ponowoczesności, [w:] tenże, Ponowoczesność jako źródto cierpień, Warszawa 2000, s. 133-153, Spojrzenia. Literatura Postmodernizmu. 
Fragmentaryzacja wiąże się z kolejną cechą ponowoczesności, jaką jest dekonstrukcja (Jacques Derrida), łączona z negacją tradycji, przeszłości i autorytetów. Naczelną zasadą postmodernistów jest nieuznawanie żadnych zasad, identyfikowane z wolnością absolutną. Obok powyższych wybiórczych cech epoki ponowoczesnej należy wymienić także antyfundamentalizm (Richard Rorty), bazujący na porzuceniu wszelkich fundamentów w myśleniu filozoficznym i teoriach naukowych. Sprowadza się to do pojęcia relatywizmu, wieloznaczności i braku ciągłości niemalże w każdym aspekcie życia ludzkiego. Powyższe cechy skłaniają do myślenia o epoce ponowoczesnej w kategoriach chaosu. Interpretacja ta zasługuje na szczególną uwagę, kiedy skupimy się na miejscu jednostki i charakterze relacji międzyludzkich we współczesnym społeczeństwie.

$\mathrm{Z}$ punktu widzenia badań socjologicznych istotną cechą ponowoczesności jest brak ściśle określonej tożsamości jednostki, stąd teza Baumana, iż kolejne wcielenia jednostki zmieniają się równie szybko i gruntownie, co obrazy w kalejdoskopie $e^{3}$. Wpływa to na plastyczność zachowań i różnorodność form kształtowania relacji interpersonalnych. Gwałtowne tempo i szeroki zasięg zmian społecznych przyczyniły się również do załamania tożsamości zbiorowej. Dominic Strinati w pracy o kulturze popularnej wyraża przekonanie, iż jesteśmy świadkami stopniowego zanikania tradycyjnych $i$ wysoko cenionych ram odniesienia, dzięki którym ludzie mogli określać siebie i swoje miejsce w spoteczeństwie, a także czuć sie względnie bezpiecznie w tożsamościach osobistych i zbiorowych (klasa społeczna, rodzina, społeczności lokalne, wspólnoty religijne, państwo narodowe $)^{4}$. Przyczyn załamania się tożsamości zbiorowej można upatrywać także w negacji tradycji i braku autorytetów. Doświadczenie młodych pokoleń nie ma odpowiednika w doświadczeniu rodziców czy dziadków. Robert Geisler zauważa, iż przodkowie nie dostarczaja żadnego wzorca zachowań, które można by wykorzystać w praktyce. W tym ujęciu jednostki czerpia wzory zachowań od swoich rówieśników ${ }^{5}$. W zjawisku tym należy podkreślić rolę mass mediów i kultury popularnej, która sprowadza się do tego, iż znaki kultury popularnej i obrazy w mediach zdominowały nasze rozumienie rzeczywistości oraz sposób, w jaki określamy samych siebie i otaczający nas świat ${ }^{6}$. Instytucje medialne poprzez mnogość i różnorodność wzorców oraz wzrost szybkości przekazu komunikatów wpływają na konstrukcję tożsamości jednostkowej i zbiorowej w społeczeństwie ponowoczesnym ${ }^{7}$. Z tego względu badacze zwracają uwagę na dominację obrazów nad narracją ${ }^{8}$, która przejawia się w konsumpcji obra-

Tenże, Dwa szkice o moralności ponowoczesnej, s. 16.

4 D. Strinati, Postmodernizm i kultura popularna, [w:] tenże, Wprowadzenie do kultury popularnej, przeł. W. Burszta, Poznań 1998, s. 190.

$5 \quad$ R. Geisler, Jednostka i spoteczeństwo..., s. 98.

$6 \quad$ Na ten temat zob. D. Strinati, Postmodernizm i kultura popularna, s. 179.

7 Marshall McLuhan jest twórcą terminu „globalna wioska” (ang. global village), oznaczającego społeczność globalną, charakteryzującą się wspólną wiedzą i łatwymi drogami wymiany informacji. Zob. M. McLuhan, Wybórpism, wybór J. Fuksiewicz, wstęp K. T. Toeplitz, przeł. K. Jakubowicz, Warszawa 1975.

8 Badacze postmodernizmu ujmują ten proces jako „schyłek metanarracji”, na który duży wpływ miał zanik rozumienia historii jako stałej linearnej narracji, jasnej sekwencji zdarzeń. Zob. D. Strinati, Postmodernizm i kultura popularna, s. 181. 
zów i znaków dla nich samych, a nie ze względu na ich wartość i użyteczność. Media przyjęły rolę banku obrazów, z których czerpie się wiedzę o współczesnych trendach kulturowych. Jednocześnie uwidacznia się istotna cecha McLuhanowskiej „globalnej wioski” - zacieranie różnic kulturowych.

Powyższa próba określenia ponowoczesności i postmodernizmu jest niekompletna, a proponowane definicje i cechy dystynktywne epoki zostały wybrane ze względu na współczesne kreacje subkultur młodzieżowych. Pod uwagę wzięto te cechy ponowoczesności, dzięki którym łatwiej będzie przeprowadzić refleksję nad zmianami w obrębie ruchów młodzieżowych. Na plan pierwszy wysuwa się teza o ponowoczesnym chaosie, a co za tym idzie miejscu jednostki we współczesnym świecie. Istotne dla naszych rozważań będą także wymienione cechy postmodernizmu: brak spójności, fragmentaryzacja świata, czasu i przestrzeni, rozproszenie i brak jednoznacznych kryteriów wartości i autorytetów. Należy przy tym podkreślić, że artykuł ten nie ma na celu dyskredytacji epoki ponowoczesnej i postmodernizmu, co przy ogólnym zestawieniu wymienionych cech może wysuwać się na pierwszy plan. Badacze odnoszą się do obecnych przemian w sposób niejednoznaczny, czego dowodem może być fakt, iż pomimo usilnych starań nie stworzono jeszcze spójnej teorii postmodernizmu, a opis wciąż niezakończonej epoki ponowoczesnej nadal budzi wiele wątpliwości. Istotą niniejszych rozważań jest uznanie postmodernizmu za prąd, który kieruje naszą uwagę ku współczesnym przemianom kulturowym, wyczulając na zmienność relacji kultura-społeczeństwo, jednostka-społeczeństwo, a także na metateoretyczny charakter samej kultury ${ }^{10}$.

\section{SUBKULTURY MŁODZIEŻOWE W UJĘCIU PONOWOCZESNYM}

Epoka ponowoczesna oferuje współczesnemu człowiekowi niespotykany zasób możliwości konstruowania siebie i własnej tożsamości. Jednak przy całej tej różnorodności nie daje mu wskazówek, jakiego wyboru należy dokonać. Jest to związane z samą istotą ponowoczesnego porządku, w którym każdy wybór jest jednym z nieskończenie wielu możliwych. Nie można ufać żadnym autorytetom, autorytety te bowiem ciągle się zmieniają, zaś eksperci nie są w stanie wykreować jednej, spójnej wizji rzeczywistości. Ponadto środki masowego przekazu ukazują wiele różnorodnych środowisk i stylów życia, o których istnieniu człowiek prawdopodobnie nie dowiedziałby się bez ich udziału ${ }^{11}$.

Zainteresowanie opisem kreacji, funkcjonowania i fenomenem subkultur młodzieżowych, a także samej młodzieży jest obecne na gruncie nauki, polityki i mediów

Tamże, s. 180 .

10 M. Featherstone, Postmodernizm i estetyzacja życia codziennego, przeł. P. Czapliński, J. Lang, [w:] Postmodernizm. Antologia przektadów, wybór i oprac. R. Nycz, Kraków 1997, s. 299.

11 A. Giddens, Nowoczesność i tożsamość. „Ja” i spoteczeństwo w epoce późnej nowoczesności, przet. A. Szulżycka, Warszawa 2001, s. 114-115, Biblioteka Socjologiczna. 
od kilkudziesięciu lat. Przełomowy w postrzeganiu młodości (wieku młodzieńczego) był okres powojenny, kiedy to w wyniku uznania wagi wykształcenia w życiu człowieka, a co za tym idzie poprzez masowy udział szerokich grup młodych ludzi w procesie edukacji wydłużył się okres określany jako „młodość”. Zmianie uległo także dotychczasowe znaczenie tej fazy życia: wiek młodzieńczy stał się samoistną wartością jako odrębny fakt kulturowy ${ }^{12}$. W drugiej połowie XX w. można także zauważyć na Zachodzie gwałtowny protest młodzieży wobec świata dorosłych, postawę buntu, która na taką skalę nie miała miejsca w poprzednich stuleciach. Poprzez głoszenie własnej, nowej i przeciwstawnej ideologii młodzież zaznaczała swoją obecność w życiu społecznym. Sprzeciw wyrażano przez noszenie specyficznego dla danej grupy stroju, emocjonalną twórczość i swoisty język, określany jako „slang młodzieżowy”. Procesy zachodzące w obrębie społeczeństwa powojennego przykuły uwagę socjologów, wśród których pierwszą próbę terminologicznego ustalenia zachodzących zmian podjął Milton Myron Gordon, uznawany za twórcę terminu „subkultura” (łac. sub + cultura - podkultura $)^{13}$. Termin ten niezwykle szybko wszedł do światowego słownika pojęć, ulegając licznym modyfikacjom i próbom doprecyzowania. Mimo to współcześnie „subkultura” nie posiada jednoznacznej definicji i jest rozmaicie interpretowana. Zaznaczmy, iż subkultura dotyczy grupy społecznej i jej kultury, wyodrębnionej według jakiegoś kryterium, np. zawodowego, politycznego, etnicznego, religijnego czy demograficznego. Do ostatniej z wymienionych należy zaliczyć subkulturę młodzieży, której liczne synonimy (terminy: „kultura alternatywna”, „kontrkultura”, „podkultura młodzieżowa”, ,antykultura”, „spontaniczna kultura młodzieżowa”) zostały utrwalone na gruncie polskich badań socjologicznych ${ }^{14}$.

Opis poszczególnych terminów oraz spór co do powiązania subkultury z pojęciem kontrkultury czy kultury alternatywnej nie stanowi przedmiotu rozważań niniejszego artykułu. Jednak konieczność określenia terminu „subkultura” skłania nas do przyjęcia

12 T. Bąk, Wspótczesne uwarunkowania kreacji subkultur mtodzieżowych, Warszawa 2008, s. 18-19. W cytowanym rozdziale autor wskazuje na przedwojenny stosunek do młodości, sięgający XIX w., ujmujący ją jako krótki okres wzrostu i oczekiwania na pełnienie funkcji w świecie dorosłych. Zob. tamże, s. 16-19.

13 M. M. Gordon definiował subkulturę jako kombinację mierzalnych sytuacji spotecznych, takich jak: pozycja klasowa, pochodzenie etniczne, terytorialne, miejsce zamieszkania w mieście lub na wsi oraz przynależność religijna, tworzacych w potaczeniu funkcjonalna jedność wywierająca na jednostkę catościowy wptyw. M. M. Gordon, The Concept of the Sub-Cultur and Its Application, „Social Forces” 1947, t. 26, s. 40, cyt. za: T. Bąk, Wspótczesne uwarunkowania..., s. 22-23.

14 W niektórych badaniach przyjmuje się także podział subkultury na trzy etapy: subkultura młodzieżowa jako faza wstępna, czyli etap odróżnienia się od reszty społeczeństwa, głównie przez zewnętrzne atrybuty; okres kontrkultury, rozumiany jako uświadomienie własnej odrębności pokoleniowej i kulturowej oraz związany z tym protest przeciwko zasadom funkcjonowania oraz wartościom tworzącym fundament społeczeństw danego kręgu kulturowego; faza kultury alternatywnej - stadium najbardziej dojrzałe, charakteryzujące się totalną krytyką zastanego świata dorosłych i próbą kreowania wzorców i zachowań pozytywnych. Społeczności alternatywne są nastawione raczej na twórczą aktywność na obrzeżach głównego nurtu kulturowego niż atakowanie starego systemu. Zob. M. Filipiak, Od subkultury do kultury alternatywnej. Wprowadzenie do subkultur mtodzieżowych, Lublin 1999, s. 15. 
często cytowanej w polskich pracach z zakresu socjologii definicji Mirosława Pęczaka: subkultura to względnie spójna grupa spoteczna pozostająca na marginesie dominujacych $w$ danym systemie tendencji życia spotecznego, wyrażajaca swoją odrębność poprzez zanegowanie lub podważanie utrwalonych i powszechnie akceptowanych wzorów kultu$r y^{15}$. Przy czym należy zaakcentować, iż subkultura stanowi część kultury, jednak aby można było o niej mówić w tych kategoriach, powinna odznaczać się odrębnością od dominującej kultury w zakresie pewnych wartości i norm postępowania. Członkowie subkultury reprezentują segment kultury i działają w ramach ogółu społeczeństwa ${ }^{16}$. Pomijając różnorodne podziały i typologie grup subkulturowych ${ }^{17}$, proponujemy ujęcie subkultury młodzieżowej z uwzględnieniem cech przesądzających o jej specyfice: oryginalne formy ekspresji twórczej, elementy mistyczno-folklorystyczne, specyficzny system semantyczny, swoisty sposób porozumiewania się, wspólne spędzanie wolnego czasu oraz hierarchia w obrębie członków grupy ${ }^{18}$. Komponenty te pozwalają scharakteryzować poszczególne odmiany subkultur z ukazaniem różnic i podobieństw między nimi.

Wypracowane w latach 70. i 80. XX w. podejście badawcze w opisie istniejących subkultur młodzieżowych w obecnych czasach wydaje się niewystarczające. Krytyce poddawany jest zwłaszcza pogląd na subkultury młodzieżowe w kategorii oderwania tych grup od kultury dominującej oraz spojrzenie na członków konkretnych subkultur przez pryzmat ich sytuacji ekonomicznej i bytowej. Obecnie część teoretyczna wielu prac jest jedynie uzupełnieniem dla „badań w terenie”. David Muggleton wysuwa tezę, zgodnie z którą należy zerwać z „realistyczną” postawą względem rzeczywistości społecznej i dać pierwszeństwo postawie „nominalistycznej”, zakładającej, że jedynie zjawiska empiryczne mogą być podstawą naszej wiedzy o rzeczywistości ${ }^{19}$. Ponadto uwagę badaczy skupia transformacja w obrębie spontanicznych ruchów młodzieżowych, wynikająca z nastania epoki ponowoczesnej. Pomocne w tym ujęciu są próby określenia kulturowych cech postmodernizmu, a także miejsca jednostki we współczesnym świecie. Niemniej jednak większość badaczy dostrzega znaczny wpływ epoki nowoczesnej ${ }^{20}$

15 M. Pęczak, Maty stownik subkultur mtodzieżowych, Warszawa 1992, s. 4, Wyktady Otwarte UMCS, 29.

16 W przypadku wyznawania wartości sprzecznych z kulturą dominującą możemy mówić o subkulturach dewiacyjnych. Zob. T. Bąk, Wspótczesne uwarunkowania..., s. 23.

17 Na ten temat zob. T. Paleczny, Kontestacja. Formy buntu we wspótczesnym spoteczeństwie, Kraków 1997, s. 157-185, Prace Instytutu Polonijnego Uniwersytetu Jagiellońskiego.

18 Cechy te nie stanowią obowiązkowych wyznaczników subkultur. Zob. V. Tarnavskyi, Dzieci swoich czasów. Ruchy mtodzieżowe w Rosji a zmiany kulturowe po upadku ZSRR, Warszawa 2007, s. 98-99.

19 D. Muggleton, Wewnątrz subkultury. Ponowoczesne znaczenie stylu, przel. A. Sadza, Kraków 2004, s. 29, Cultura.

20 Epoka nowoczesna w tym kontekście poprzedza ponowoczesność. Terminem tym określa się okres historyczny, który w Europie rozpoczął się w dobie Oświecenia w wyniku przemian intelektualnych, kulturalnych i społecznych, zaś swoją pełnię osiągnął w społeczeństwie przemysłowym. Anthony Giddens w sposób umowny i skrótowy określa tym terminem nowoczesne społeczeństwa lub cywilizację przemysłową, gdzie świat postrzegany jest jako transformowalny przez ludzkie działania, gdzie funkcjonują skomplikowane instytucje gospodarcze, w tym produkcja przemysłowa i gospodarka rynkowa, oraz 
i modernizmu na dzisiejsze kreacje subkultur. $Z$ tego względu zasadne wydaje się stanowisko Baumana, uznającego epokę ponowoczesną za okres ponownego spojrzenia na nowoczesność z jednoczesną próbą jej analizy i oceny ${ }^{21}$.

Jedną z istotnych cech nowoczesności, wpływającą na współczesną wizję jednostki, był indywidualizm, oznaczający wolność i autonomię człowieka w jego działaniach. Badacze modernizmu wskazują, że indywidualizm przejawiał się we wszystkich formach zachowania jednostek w społeczeństwie: w działalności politycznej, ekonomicznej i kulturowej22. Jednak, jak stwierdza Anthony Giddens, człowiek poprzez „uwolnienie” (Zbigniew Bokszański stosuje określenie „emancypacja” rodzinna, społeczna, ekonomiczna, geograficzna, kulturowa i moralna ${ }^{23}$ ) stracił tradycyjne drogowskazy wskazujące mu, kim być, jak żyć i co robić, czyli mówiąc najogólniej - wyznaczniki swojej tożsamości ${ }^{24}$. Tożsamość zaznacza naszą odrębność od innych, a także dotyczy cech, jakie jednostce przypisują inni ludzie. Procesy urbanizacji, industrializacji i załamanie wcześniej istniejących formacji społecznych osłabiły siłę oddziaływania dziedziczonych reguł i konwencji ${ }^{25}$. W odniesieniu do członków ponowoczesnych subkultur Muggleton stosuje kategorię hiperindywidualizmu, który na poziomie uczestnika subkultury wiąże się z tożsamością fragmentaryczną, będącą jedną z cech postsubkultur ${ }^{26}$. Tożsamość fragmentaryczna opiera się na mniej oczywistej i mniej jednoznacznej identyfikacji z grupą, co określane jest mianem „różnicującej indywidualności”, a więc sposobem wyrażania własnej tożsamości członków subkultury poprzez wyraźne zaznaczenie różnic dzielących ich od grupy odniesienia ${ }^{27}$. U podstaw tego toku rozumowania leży pojęcie ponowoczesnej różnorodności, powierzchowności i ulotności tożsamości zbiorowej, przejawiającej się w wielorakich możliwościach nakładania „masek” i pełnienia odmiennych funkcji społecznych ${ }^{28}$. Uzasadnieniem tej tezy może być postawa jedynie częściowej, niepełnej asymilacji z subkulturą, odbywającej się na poziomie odgrywania roli punka czy hipisa.

Rozpad zbiorowej tożsamości jest zauważalny także na poziomie atrybutyki. Przyjmuje to formę określaną jako bricolage elementów należących do danej subkultury i stylu konwencjonalnego ${ }^{29}$. Z tego względu można mówić o heterogenizacji stylu

gdzie istnieją instytucje polityczne, w tym państwo narodowościowe i demokracja masowa. Definicję przytaczam za: A. Giddens, Nowoczesność i tożsamość...

21 Z. Bauman, Etyka ponowoczesna, przeł. J. Bauman, J. Tokarska-Bakir, Warszawa 1996, s. 8.

22 R. Geisler, Jednostka i spoteczeństwo..., s. 77-83.

23 Z. Bokszański, Indywidualizm a zmiana spoteczna. Polacy wobec nowoczesności. Raport z badań, Warszawa 2007, s. 77.

24 A. Giddens, Socjologia, przeł. A. Szulżycka, Warszawa 2004, s. 52.

25 Tamże, s. 54.

26 D. Muggleton, Wewnątrz subkultury..., s. 109-110. Określenie „postsubkultura” zostało zaczerpnięte z pracy Muggletona i oznacza subkulturę w ujęciu ponowoczesnym.

27 Tamże, s. 82-89.

28 Na temat tożsamości zbiorowej i indywidualnej zob. Z. Bokszański, Tożsamości zbiorowe, Warszawa 2005.

29 D. Muggleton, Wewnatrz subkultury..., s. 109. 
w obrębie danej postsubkultury, która zastąpiła homogenizację, swoistą dla wcześniejszych kulturowych ruchów młodzieżowych. Mobilność stylu powoduje osłabienie granic między różnymi subkulturami (pozornie odległymi) i wyklucza reakcje opozycyjne względem innych grup. Zabawa modą, zapożyczanie elementów stroju od innych subkultur jest traktowana jako przyjemność i nakierowana na widowisko, szokowanie społeczeństwa. Dlatego badacze są zgodni, iż współczesna fascynacja wizerunkiem zastąpiła nacisk na poglądy i wartości ${ }^{30}$. Moda postsubkultur oznacza włączenie się w estetyczną grę, skupioną na hedonizmie i chęci epatowania innością również w odniesieniu do własnej subkultury.

Cechą szczególną ponowoczesności jest zlikwidowanie możliwości oryginalności i autentyczności subkultury. Stanowi to konsekwencję wszechogarniającej władzy współczesnych środków masowego przekazu. W związku z powyższym nie może być mowy o oryginalnym, „czystym” momencie twórczej innowacji subkulturowej, proces ten bowiem poprzedza komercjalizacja. Subkultury młodzieżowe stały się częścią kultury rozpowszechnianej za pośrednictwem mediów. Wpływ mass mediów przekłada się także na zanik bezpośrednich kontaktów między członkami subkultury. Marek Jędrzejewski określa współczesne subkultury jako „medialne” w odróżnieniu od klasycznych, dla których bezpośredni kontakt z grupą ludzi wyznających tożsame wartości stanowił kwintesencję przynależności do subkultury ${ }^{31}$. Dominująca rola mediów, zwłaszcza Internetu, z jednej strony przybliża ludzi z odległych zakątków świata (efekt „globalnej wioski”), z drugiej natomiast niesie odmienną jakość socjalizacji młodzież częściej spotyka się w wirtualnym świecie niż face to face. Z tego względu, Jędrzejewski wyróżnia specyficzne subkultury cyberpunków czy graczy komputerowych, dla których miejscem socjalizacji jest rzeczywistość cybernetyczna ${ }^{32}$. Socjolog wskazuje na zagrożenia, jakie niesie poszukiwanie wspólnoty „w sieci”: pogłębiający się dystans między starszym a młodszym pokoleniem, ryzyko uzależnienia komputerowego, zanik kultury żywego słowa, kontakt nieletnich z przemocą i wulgarnymi treściami ${ }^{33}$.

Cechy współczesnych subkultur w większości prac badawczych są opisywane w opozycji do subkultur klasycznych, występujących w XX w. Część z nich została poddana analizie w niniejszym fragmencie, pozostałe proponujemy przedstawić $\mathrm{w}$ formie zestawienia dwóch zbiorów cech typów idealnych, prezentowanych przez subkultury i postsubkultury. W tym celu załączamy tabelę stworzoną przez Muggletona, mając nadzieję, iż jej prosty przekaz przybliży badaną formę przejścia subkultur młodzieżowych od nowoczesności do ponowoczesności ${ }^{34}$.

30 Tamże, s. 49, 69.

31 M. Jędrzejewski, Od subkultur klasycznych do medialnych, „Remedium” 2002, nr 10, s. 2.

32 Tamże.

33 Tamże, s. 3. Dobrym przykładem wpływu Internetu i cyberprzestrzeni na młode pokolenie jest film w reżyserii Jana Komasy zatytułowany Sala samobójców (2011).

34 Tabela została skopiowana z pracy: D. Muggleton, Wewnatrz subkultury..., s. 69. 


\begin{tabular}{|c|c|}
\hline NOWOCZESNOŚĆC & PONOWOCZESNOŚĆ \\
\hline Tożsamość grupowa & Tożsamość fragmentaryczna \\
\hline Homogeniczność stylu & Heterogeniczność stylu \\
\hline Wyraźne określenie granic & Słabo określone granice \\
\hline Subkultura określa tożsamość & Wielorakie źródła tożsamości \\
\hline Wysoki stopień zaangażowania & Niski stopień zaangażowania \\
\hline Przynależność do grupy postrzegana jako stała & Przemijająca więź z grupą \\
\hline Niski stopień mobilności subkulturowej & Wysoki stopień mobilności subkulturowej \\
\hline Nacisk na poglądy i wartości & Fascynacja stylem i wizerunkiem \\
\hline Gest politycznego oporu & Nastroje apolityczne \\
\hline Negatywny stosunek do mediów & Pozytywny stosunek do mediów \\
\hline Świadomość własnej autentyczności & Celebracja nieautentyczności \\
\hline
\end{tabular}

\section{PONOWOCZESNOŚĆ W ROSJI. PONOWOCZESNY WYMIAR SUBKULTUR MŁODZIEŻOWYCH W ROSJI}

Proponowane ujęcie ponowoczesności odnosi się do kultury świata zachodniego. Liczba prac, stanowisk badawczych oraz wieloaspektowa analiza zachodzących zmian pozwoliły wypracować szeroki ogląd zjawisk i ująć trwającą epokę w kategoriach opisowych. Odmiennie rzecz ma się z postmodernizmem w odniesieniu do kultury rosyjskiej, na której gruncie twierdzenie o trwaniu ponowoczesności jest jak najbardziej uzasadnione. Jednak należy wziąć pod uwagę fakt, że wszelkie dyskusje, badania i wnioski dotyczące postmodernizmu rozpoczęły się w Rosji ze sporym opóźnieniem, ich zainicjowanie możliwe było bowiem dopiero w połowie lat 80 . XX w., a więc z chwilą nastania pierestrojki. Upadek Związku Radzieckiego umożliwił wydanie dzieł myślicieli społecznych, których na Zachodzie od lat uznawano za klasyków postmodernizmu. Pod ich wpływem rodzimi badacze rozpoczęli poszukiwania cech ponowoczesności w kulturowej specyfice Rosji. Ów dysonans na terenie Rosji między dwoma następującymi po sobie okresami historycznymi wyraził Ilja Iljin: w okresie postradzieckim Rosja znalazta się w sytuacji niejednoznacznej. Z jednej strony nie rozwiązano do końca problemów zwiazanych z procesem modernizacji kraju [...] $Z$ drugiej strony Rosja znalazta się w'wiecie, w którym granice kulturowe zostaty zniesione. Wptywa to na przeniknięcie do kraju idei postmodernistycznej wraz z nowymi technologiami. W latach 90. Rosja byta krajem, który znalazt się między dwoma biegunami - topatą a Internetem ${ }^{35}$. Badacz stoi na sta-

35 И. ИАьин, Поведение потребителей, Санкт-Петербург 2000, суt. za: V. Tarnavskyi, Dzieci swoich czasów, s. 33. 
nowisku, iż uczynienie kolejnego kroku na drodze rozwoju cywilizacyjnego i kulturowego jest uzależnione od wpływów Zachodu, dzięki którym zostaną porzucone tradycyjne narzędzia rolnicze na rzecz idei powszechnej komputeryzacji i technicyzacji ${ }^{36}$. U podstaw takiego twierdzenia leży przekonanie, iż Rosja w gruncie rzeczy nie różni się od krajów zachodnich, a jedynie kulturowe trendy przybywają do niej z opóźnieniem. Wielu badaczy rosyjskich nie zgadza się z tym stanowiskiem, traktując - za Umberto Eco - postmodernizm nie jako zjawisko chronologiczne odznaczające się poziomem zaawansowania technologicznego, lecz świadomościowe. Dlatego główny obszar ich badań dotyczy przekształceń w sferze kultury po upadku ZSRR.

Pierwszym i niepodważalnym spostrzeżeniem kierującym naszą uwagę $\mathrm{w}$ stronę rosyjskiego postmodernizmu jest całkowity rozpad kultury monolitycznej, której przejawy wdarły się w zbiorową świadomość mieszkańców Związku Radzieckiego. Występująca w tej sferze różnorodność stylów, form i sposobów na życie nie pozostawia miejsca na klarowne podziały, w których Rosjanie zostali zamknięci w okresie istnienia ZSRR. Ponadto pojęcia tradycji i normy uległy rozmyciu ${ }^{37}$. W ten sposób człowiek rosyjski znalazł się w sytuacji głębokiego kryzysu, poczynając od sfery ekonomicznej, na świadomościowej kończąc. Nie bez powodu świadomość człowieka ponowoczesnego określa się mianem „schizofrenicznej”, co w pełni przystaje do kondycji psychicznej Rosjan doby transformacji. W kategoriach kryzysu ujmuje się także epokę ponowoczesną na Zachodzie. Współczesne zmiany cywilizacyjne niosą szereg zagrożeń, do których zaliczane są katastrofy ekologiczne, szybki przyrost naturalny, zagrożenia polityczne, wreszcie kryzys na gruncie świadomości jednostek, określany skrótowo jako depersonalizacja ${ }^{38}$. Jednak na gruncie rosyjskim ów kryzys ma podwójne znaczenie. Badaczki postmodernizmu rosyjskiego ujęły to następująco: sytuacja duchowa w Rosji w ostatnich latach epoki sowieckiej wyraźnie ukazata zjawiska kryzysowe, zarówno wspólne dla wszystkich krajów rozwiniętych, jak i charakterystyczne tylko dla naszego kraju. Świadomość kryzysowa ujawnita się $w$ dzietach literatury i sztuki, a także w niektórych pracach filozoficznych ${ }^{39}$. Badacze postmodernizmu na gruncie rosyjskim, opisując kulturę społeczeństwa postradzieckiego, niezwykle często odnoszą się do koncepcji kryzysu ponowoczesnego jako ciężkiego stanu przejściowego, poczucia braku stabilności i równowagi ${ }^{40}$. Stan kryzysu kultury trafnie opisał Jurij Lewada: spoteczeństwo radzieckie byto zupetnie nieprzygotowane na ,inwazje” przyzwalających na wątpienie wartości, na wptywy masowości i średniego gustu, na nieobowiązkowość norm, które nie sa już narzucane za

36 V. Tarnavskyi, Dzieci swoich czasów..., s. 33.

37 Tamże, s. 36.

38 Szerzej na ten temat zob.: R Geisler, Jednostka i spoteczeństwo..., s. 25-33; Wobec kryzysu kultury. Z filozoficznych rozważań nad kultura wspótczesną, red. L. Grudziński, Gdańsk 1993; Z. Bauman, Ponowoczesność jako źródto...

39 И. С. Андреева, $\Lambda$ В. Федорова, Постмодернизм: за и против, [w:] На путях постмодернизма. Сборник обзоров и рефератов, red. И. С. Анареева [i in.], Москва 1995, s. 36. Tłumaczenie własne - M.K.

40 Stan ten trafnie określił Aleksander Sołżenicyn, nazywając go „Rosją w zapaści”. Zob. A. Sołżenicyn, Rosja w zapaści, przeł. J. Zychowicz, Warszawa 1999. 
pomoca autorytarnych mechanizmów ${ }^{41}$. Rozkład istniejącego modelu kulturowego przyczynił się w największym stopniu do kryzysu tożsamości mieszkańców dzisiejszej Rosji. Błogie poczucie pewności własnych przekonań i znajomości otaczającego świata rozpadło się na kawałki, pozostawiając uczucie pustki i niepewności jutra. Viktor Tarnavskyi wyraża przekonanie, iż podobne odczucia w epoce globalizacji dotyczą większości społeczeństw. Jednak ze względu na catoksztatt uwarunkowań, niepokój jako uczucie permanentne towarzyszy w ostatnich latach mieszkańcom Rosji w stopniu o wiele większym niz ma to miejsce w krajach zachodnich ${ }^{42}$.

W kontekście współczesnych zmian kulturowych w Rosji doniosłe znaczenie mają środki masowego przekazu. Zadaniem radzieckich mediów było przekazywanie obiorcy określonego obrazu rzeczywistości, dlatego przekłamania i przemilczenia były odgórnie wpisane w ich funkcjonowanie. Po upadku ZSRR reakcją na te działania była eksplozja tematów uznanych wcześniej za społeczne tabu i związana z tym chęć naświetlenia zjawisk uznawanych za dewiacje społeczne ${ }^{43}$. Inną cechą mediów rosyjskich przełomu lat 80. i 90. XX w. był tzw. „szok informacyjny”. Zetknięcie się Rosjan z ogromną ilością nowych informacji zaowocowało przeniknięciem do ich świadomości pokaźnej liczby nowych symboli, znaków, obrazów i sensów ${ }^{44}$. Przeciętny odbiorca mass mediów był zmuszony uporać się z przyswojeniem i uporządkowaniem stanu rzeczy na własny rachunek. Paradoksalnie, młodzi ludzie poradzili sobie z tym najlepiej, szybko odnajdując się w świecie nowych znaczeń i wartości ${ }^{45}$.

Badając fenomen rosyjskich postsubkultur, należy w pierwszej kolejności zwrócić uwagę na wpływ mediów. Ich demokratyzacja, a także nieograniczony dostęp do Internetu wpłynęły na swobodne przenikanie informacji na temat zachodnich subkultur. Z tego względu większość nowych kulturowych grup młodzieżowych w Rosji powstała jako wynik naśladownictwa czy też zapożyczenia wzorców zachodnich, co jest określane przez Leonida Ionina jako „inscenizacja kulturowa” ${ }^{46}$. Nie oznacza to bynajmniej, iż na gruncie rosyjskim nie powstały subkultury charakterystyczne dla rodzimej specyfiki kulturowej. Do ruchów takich zaliczyć można niezwykle aktywne grupy autostopowiczów (ros. автостопщики) i rolewików (ros. ролевики, ролевое движение), które na większą skalę istnieją tylko w krajach byłego Związku Radzieckiego ${ }^{47}$. Jednak śledząc historię dwudziestowiecznych subkultur na terenie ZSRR, trudno nie zgodzić

41 Ю. Аевада, От мнений к пониманию. Сочиологические очерки 1993-2000 годов, Москва 2000, сут. za: V. Tarnavskyi, Dzieci swoich czasów..., s. 43.

42 V. Tarnavskyi, Dzieci swoich czasów..., s. 60.

43 Symptomy tej reakcji były zauważane przed upadkiem ZSRR, a ich wyrazem była wprowadzona przez Michaiła Gorbaczowa gtasnost.

44 V. Tarnavskyi, Dzieci swoich czasów..., s. 28.

45 Na temat szybkości przyswajania nowości wśród młodego pokolenia zob. M. Mead, Kultura i tożsamość. Studium dystansu międzypokoleniowego, wstęp W. Adamski, przeł. J. Hołówka, Warszawa 1978, Biblioteka Socjologiczna.

46 Za: V. Tarnavskyi, Dzieci swoich czasów..., s. 130.

47 Tamże. Autor książki Dzieci swoich czasów poświęca charakterystyce autostopowiczów i rolewików dwa rozdziały swej pracy. Zob. tamże, s. 134-142, 187-278. 
się z faktem, iż „inscenizacje kulturowe” miały miejsce jeszcze w okresie izolacji bloku wschodniego od świata zachodniego. Ówczesna młodzież za pośrednictwem mediów zdobywała informacje na temat zarówno subkultur, jak i trendów w muzyce. Mieszkańcy ZSRR mieli do czynienia z dwoma źródłami informacji: regularnie zagłuszanymi radiostacjami zagranicznymi (BBC, Głos Ameryki) oraz nielegalnie dostarczanymi czasopismami z Zachodu. Drugim źródłem były radzieckie media oficjalne, w których prezentowany obraz zachodniej kultury był nieobiektywny i zdeformowany. W prasie dominował jedyny możliwy, skrajnie „optymistyczny” sposób przedstawiania tematyki związanej z młodzieżą. Niemniej jednak dla poszukującej inspiracji na Zachodzie młodzieży radzieckiej nawet zafałszowany wizerunek grup społecznych czy trendów w muzyce i modzie stawał się impulsem do tworzenia wzorców kulturowych zapożyczonych zza żelaznej kurtyny. Jednym z ważniejszych bodźców do powstania subkultury punków (ros. панк) na obszarze radzieckim były właśnie publikacje prasowe, w których przedstawiano zachodnich punków jako reprezentantów degradującego się spoteczeństwa kapitalistycznego ${ }^{48}$. Wbrew zamierzeniom autorów krytycznych artykułów „odrażający” obraz członka tej subkultury wzbudził szerokie zainteresowanie wśród radzieckiej młodzieży i szybko znalazł naśladowców. Podobnie krytyczny stosunek prasy do pierwszej radzieckiej subkultury, określanej w Polsce mianem bikiniarzy (ros. стиляги), spowodował gwałtowny wzrost liczby jej członków ${ }^{49}$.

Istotną cechą współczesnych subkultur w Rosji jest utrata radykalnie opozycyjnego charakteru i poczucia misji. Buntowniczość i krytyczny stosunek przynajmniej do części wartości dominujących $\mathrm{w}$ danym społeczeństwie to jedna z ważniejszych cech grup młodzieżowych XX w. Z tego powodu niektóre subkultury uznawane były za młodzieżowe grupy kontestacyjne (skini, punki). Muggleton wyraża przekonanie, iż w obliczu rozpadu społeczeństwa masowego brakuje spójnej dominującej kultury, wobec której subkultura mogłaby wyrażać swój opór ${ }^{50}$. Również obecna sytuacja polityczna nie jest traktowana jako powód do protestów, co najwyżej do krytyki i niezadowolenia. Przyczyną tego może być brak wiary w możliwość radykalnej zmiany sytuacji społeczno-politycznej. Nawet ci, którzy deklarują powstanie nowego ucisku

\section{Tamże, s. 122.}

49 Pierwszą oficjalną wiadomością prasową o stilagach był felieton Cmuлsza D. Bielajewa, zamieszczony w rubryce Tunь, уходящие в прошлое, opublikowany w satyrycznym czasopiśmie „Крокодил” w 1949 roku. W kolejnych numerach czasopisma, a także w gazecie „Правда” pojawiały się prześmiewcze informacje o członkach tej subkultury, charakteryzowanych jako próżniacy, pijacy i potencjalni zdrajcy. Tekst pierwszego felietonu o stilagach dostępny na stronie internetowej: http://flanagan. $\mathrm{ru} / \mathrm{d}$-belyaev-laquo-stilyaga-raquo-iz-serii-laquo-tipy-uxodyashhie-v-proshloe-raquo-krokodil-1949-nbsp-7-s-10.html, 26 IV 2012. Na temat bikiniarzy zob. M. Cichopek, Bikiniarze. Pierwsza polska subkultura, Warszawa 2005; Bikiniarze, [w:] M. Pęczak, Maty stownik subkultur mtodzieżowych, s. 12 -14; Bikiniarze, [w:] B. Prejs, Bunt nie przemija. Bardzo podręczny stownik subkultur mtodzieżowych, Katowice-Warszawa 2004, s. 20-21. O stilagach pisali m.in. V. Tarnavskyi, Dzieci swoich czasów..., s. 103-108; В. Славкин, Памятник неизвестному Стиляге, Москва 1996; А. Козмов, Козел на саксе, Москва 1996. Ostatni tekst dostępny na stronie internetowej: http://lib.ru/CULTURE/ MUSIC/KOZLOV/kozel_na_saxe.txt, 26 IV 2012.

50 D. Muggleton, Wewnattrz subkultury..., s. 64. 
(komercyjno-technogennego), rzadko decydują się na zajęcie bezkompromisowego stanowiska ${ }^{51}$. Współcześnie uwidacznia się zjawisko nakładania maski buntownika, jednak jest to związane z kreacją jednostek, a nie charakterem całej subkultury. Określone subkultury działają co najwyżej w wyznaczonych zawężonych kierunkach, np. ekologicznych. Niektóre zrzeszenia rosyjskich hippisów wypowiadają się publicznie w obronie zwierząt, mniejszości seksualnych i potrzebujących. Świadczą o tym akcje charytatywne, polegające na rozdawaniu wegetariańskiego jedzenia, znane pod nazwą „Food Not Bombs” („Jedzenie zamiast bomb”) ${ }^{52}$, pomoc domom dziecka, zachęcanie do humanitarnego traktowania zwierząt poprzez rozdawanie ulotek, rozwieszanie plakatów czy oblewanie skórzanej odzieży przechodniów czerwoną farbą. Dlatego, choć na poziomie deklaracji atakuje się cały „system”, w rzeczywistości jest to domena nielicznych ekstremistycznych ugrupowań ${ }^{33}$.

Upadek Związku Radzieckiego wpłynął na przerwanie funkcjonowania subkultur rosyjskich w granicach tzw. Sistiemy (ros. Cucmena). W warunkach radzieckich Sistiema, czyli ruch zrzeszający liczne subkultury młodzieżowe (punki, hipisi, metalowcy, rokerzy i in.), posiadał wyraźnie opozycyjny charakter względem władzy. Dlatego w gruncie rzeczy Sistiema była ruchem antysystemowym, opartym na wzajemnej pomocy i braterstwie. Ideologię Sistiemy trafnie opisał członek ruchu, Jewgienij Bałakiriew, w eseju Saga o „Sistiemie”: Gtówna cecha ruchu byt proces duchowych poszukiwañ. Te wtaśnie poszukiwania prowadzity ludzi do "Sistiemy”. W obrębie ruchu istniata rotacja treśsi duchowych i intelektualnych: ogólnych informacji o różnych doktrynach, literaturze religijnej i filozoficznej, kontaktach z rozmaitymi wspólnotami [...] Otwarta intelektualność "Sistiemy" nigdy nie byta ograniczana przez jeden dogmat ${ }^{54}$. Tarnavskyi zauważa, iż spośród oddolnych ruchów mtodzieżowych w ZSRR Sistiema wykazywata najwięcejpodobieństw do środowisk kultury alternatywnej istniejacej na Zachodzie. Jednocześnie ruch ten od chwili powstania w latach siedemdziesiatych XX wieku byt zjawiskiem pozostajacym w'scistym zwiazku z ówczesna rzeczywistościa i tradycjami rosyjskiej kultury ${ }^{55}$. Unifikacja kultury radzieckiej, skąpy dopływ informacji z Zachodu oraz sztywne normy społeczne narzucane przez władzę zmusiły członków Sistiemy do odrzucenia standardów narzucanych przez spoteczeństwo i prowadzenia alternatywnego stylu życia ${ }^{56}$. Wobec powszechnego przymusu pracy większość należących do ruchu nie decydowała się na jej podjęcie, pozostając wrogami społeczeństwa. Porzucali często naukę, co podobnie jak brak pracy wiązało się z odpowiedzialnością karną. Stosunkowo często przyjmowaną metodą walki władz z hipisami czy punkami były milicyjne nagonki, podczas których hipisów bito

51 V. Tarnavskyi, Dzieci swoich czasów..., s. 131.

52 Jest to ogólnoświatowa akcja, której początki sięgają lat 80 . XX w. Szczegółowe informacje na stronie akcji: http://www.foodnotbombs.net.

53 V. Tarnavskyi, Dzieci swoich czasów..., s. 131-132.

54 Е. Балакирев, Сага о Системе, ВАадивосток 1999, [onilne] http://www.altruism.ru/sengine.cgi 15/24/17, 26 IV 2012.

55 V. Tarnavskyi, Dzieci swoich czasów..., s. 115.

56 Е. Балакирев, Сага о Системе. 
i obcinano im włosy (metody znane ze stosowania wobec stilagów). Inną formą represji było umieszczanie „odmieńców” w szpitalach psychiatrycznych, przy czym należy zaznaczyć, iż wielu męskich członków Sistiemy zgłaszało się tam dobrowolnie, by uniknąć poboru do wojska. Metody represji względem reprezentantów różnych subkultur były jednakowe, stąd niezwykle popularne w latach aktywności Sistiemy powiedzenie: Панки любят грязь, а хиппи цветьь - но всех их вместе винтлт менты (Punki wola btoto, a hipisi kwiaty, lecz razem ich gliny wsadzaja za kraty) ${ }^{57}$.

Antysystemowy charakter Sistiemy przestał mieć znaczenie z chwilą krachu państwa komunistycznego. Obecnie rzadko który członek ruchów młodzieżowych decyduje się na porzucenie edukacji. Przynależność do subkultury nie wiąże się już z całkowitym poświęceniem czasu na rzecz danej grupy. Uczestnictwo w ruchu traktowane jest jako przyjemna forma spędzania wolnego czasu, stąd aktualny wydaje się pogląd o przejściu od tożsamości grupowej do tożsamości indywidualnej. W czasach istnienia Sistiemy wyznawane poglądy i wartości dotyczyły wszystkich grup młodzieżowych skupionych w ruchu, jednoczył je bowiem wspólny antypaństwowy cel ${ }^{58}$. Sistiema jako środowisko była katalizatorem duchowego rozwoju jednostki, który w warunkach radzieckich był odgórnie hamowany. Współcześnie identyfikacja z grupą jest mniej oczywista, a członkowie postsubkultur nie mówią o sobie w kategoriach zbiorowych. Poczucie misji, charakterystycznej dla członków subkultur okresu radzieckiego, również przestało mieć znaczenie. Możemy jednak zauważyć ciągłą potrzebę jedności, spajającą młodych ludzi, których łączy wspólne zainteresowanie muzyką, podróżami czy grami komputerowymi.

Na plan pierwszy wysuwa się jednak ponowoczesny charakter subkultur, ujawniający się na poziomie specyficznego rozumienia wolności jako braku wszelkich ograniczeń, zasad i norm: wolność wszystkich od wszystkiego. Wszystko jest dozwolone prócz tego, by istniaty rzeczy niedozwolone ${ }^{59}$. Bauman charakteryzuje czasy ponowoczesne jako okres niespotykanej dotąd wolności wyboru, które jednak rzucają człowieka w stan rozdzierającej niepewności ${ }^{60}$. Współczesne ujęcie wolności jednostek ujawnia się również na poziomie przynależności do określonej grupy społecznej, narzucającej konkretne wzorce i normy postępowania. Z tego powodu określanie siebie w ramach grupowej tożsamości może sugerować ograniczenie członka danej subkultury poprzez nadanie mu etykiety hipisa, hiphopowca czy punka. Jest to rodzaj pozornej sprzeczności mię-

57 Cyt. za: V. Tarnavskyi, Dzieci swoich czasów..., s. 125.

58 Należy zaznaczyć, że Sistiema nie jest traktowana jako środowisko dysydenckie, mimo iż formy represji wobec jej członków były podobne do metod, jakie władza stosowała wobec dysydentów. Opór młodzieży skupionej w ruchu miał charakter bierny i polegał głównie na byciu poza nurtem, na marginesie społeczeństwa. Na temat Sistiemy zob. T. В. Щепанская, Система. Тексты и традищии субкультурьь, Москва 2004; тад̇, Молодежньц сообщества, [w:] Современный городский фольклор, red.. А. Ф. Белоусов [i in.], Москва 2003, s. 34-85.

59 J. Mizińska, Cóż po filozofie w czasie marnym?, [w:] Oblicza postmoderny. Teoria i praktyka uczestnictwa w kulturze wspótczesnej, red. A. Zeidler-Janiszewska, Warszawa 1992, s. 34, Wokót Przetomu Postmodernistycznego.

60 Z. Bauman, Etyka ponowoczesna, s. 31. 
dzy wolnością jednostki a przynależnością do grupy, dlatego współcześnie subkultura jest traktowana jako antystruktura, czyli zbiorowość, która nie ma ściśle określonych granic, definicji i zachowań. Istotne w tej kwestii jest poczucie własnej indywidualności oraz chęć odróżnienia się od mas.

Analiza grup subkulturowych obecnych w Rosji pozwala sformułować wniosek, iż ich funkcjonowanie, a także sam akt kreacji są tożsame z ruchami młodzieży obecnymi na Zachodzie. Nie sposób jednak przeoczyć ruchu rolewików - subkultury, która na szeroką skalę obecna jest jedynie w krajach byłego ZSRR ${ }^{61}$. Główną formą aktywności tego ruchu jest organizacja fabularnych gier terenowych, przypominających jednocześnie przedstawienie teatralne, turniej rycerski, zawody sprawnościowe i wyjazd turystyczny. Tematykę gier stanowią fabuły książek fantasy (ruch ten nazywany jest także „tolkieniści”, od nazwiska prekursora współczesnych powieści fantasy - Johna Ronalda Reuela Tolkiena) lub science fiction, a także powieści historyczne. Rolą uczestników gier jest odtworzenie określonych realiów fantastycznych i historycznych za pomocą skrupulatnie przygotowanego scenariusza, elementów scenograficznych, kostiumów i atrap broni ${ }^{62}$. Odpowiednio zorganizowana gra fabularna ma służyć stworzeniu na czas jej trwania świata alternatywnego, w którym gracz może się zanurzyć i poczuć uczestnikiem wydarzeń. Zasada tworzenia rzeczywistości równoległej jest zbieżna z subkulturą graczy komputerowych, jednak istotny jest rodzaj socjalizacji. Podczas gdy gracze komputerowi „socjalizują” się w cyberprzestrzeni, rolewicy spędzają wspólny czas „w realu”, zarówno w trakcie improwizowanych zabaw, jak i w długotrwałym procesie przygotowania scenariusza gry. W ten sposób gra fabularna staje się istotnym elementem stylu życia. Może być traktowana jako przejaw średniowiecznego karnawału, momentu wytchnienia od codziennej monotonii ${ }^{63}$. Obserwujemy tu w sposób dosłowny charakterystyczne dla ponowoczesności „nakładanie masek”, „wcielanie się w role”, tworzenie równoległego świata (simulacrum) jako dodatkowej fascynacji przestrzenią życiową. Innym odniesieniem do ponowoczesnego charakteru tej rosyjskiej subkultury jest bogata różnorodność (według Muggletona „różnicująca indywidualność”) w obrębie grupy. Subkultura ta ma wyraźnie heterogeniczny charakter, gdyż skupia członków różnorodnych środowisk, o odmiennych orientacjach politycznych i poglądach społecznych. Dla rolewika bowiem najważniejszy jest świat równoległy i rola, jaką przypada mu w nim grać. Ponadto subkultura ta nie ma wyraźnej struktury, jasno określonych granic czy form organizacyjnych.

W świetle rozważań o ponowoczesności subkultura rolewików jest o tyle inspirująca, iż posiada większość cech uznawanych za przejawy współczesnego charakteru subkultur. Jest jednocześnie ruchem „bezpiecznym”, pozwalającym na rozwój wyobraźni poprzez przenoszenie się do równoległego świata, w którym każdy może być, kim zechce, zgodnie z własną tożsamością: $w$ grze istnieje zapotrzebowanie na zdol-

$61 \quad$ Na temat tej subkultury zob. V. Tarnavskyi, Dzieci swoich czasów..., s. 187-288.

62 Tamże, s. 188-189.

63 Tamże, s. 269. Tarnavskyi powołuje się tu na koncepcję Michaiła Bachtina, dotyczącą funkcji średniowiecznego karnawału. 
ności intelektualne, emocje i dążenia, nieznajdujace zastosowania $w$ realnym życiu ${ }^{64}$. W przeciwieństwie do form socjalizacji, jakie oferuje „cyberkultura”, uczestnicy ruchu spędzają aktywnie czas wolny na spotkaniach w plenerze, kilkudniowych wyprawach, biwakach. Żyjąc w warunkach „kryzysowego społeczeństwa”, rolewicy są zdolni uczynić zamieszkaną przez siebie rosyjską przestrzeń ciekawszą i łatwiejszą do zaakceptowania.

\section{PODSUMOWANIE}

Charakteryzując współczesność jako epokę ponowoczesną, z akcentem na przedrostek po-, stajemy w miejscu, w którym dokładnie potrafimy opisać punkt wyjścia (epoka nowoczesna), jednak nie jesteśmy jeszcze w stanie określić punktu dojścia. Z tej przyczyny wszelkie opisy współczesności opierają się na dwóch stanowiskach: ponowoczesność jako przedłużenie nowoczesności lub jej zaprzeczenie ${ }^{65}$. Wynika to z traktowania obecnych czasów jako zjawiska chronologicznego, następującego po nowoczesności, po modernizmie, po industrializmie, po kapitalizmie. Takie podejście wpływa z kolei na radykalizację stanowiska badawczego: od apologii do krytyki ponowoczesności. Tymczasem podążając za koncepcją Baumana, należałoby spojrzeć na ponowoczesność, wyzbywając się osądu i niekonstruktywnej krytyki. Nie idealizując czasów współczesnych, dostrzec zalety i wskazać wady, będące przejawem niezakończonego procesu, pozostającego w relacji otwartej na możliwe zmiany. Geisler wyraża przekonanie, iż ze względu na ulegający nieustannym zmianom przedmiot oglądu konstruowanie pytań i poszukiwanie na nie odpowiedzi nie jest aktem zamkniętym, lecz stanowi podstawę do wszczęcia dalszych poszukiwań ${ }^{66}$.

Współczesne przemiany w obrębie subkultur młodzieżowych należy ująć w kontekście zmian o podłożu społecznym, które wciąż trwają i podlegają analizie. Z jednej strony można zaznaczyć niezależne od czasu cechy dystynktywne określające sens i cel zrzeszania się młodzieży w grupach subkulturowych. Są to: potrzeba akceptacji i poczucia przynależności do określonej mikrostruktury (subkultura staje się alternatywą dla rodziny, czego przyczyn upatruje się w dystansie międzypokoleniowym oraz młodzieńczym buncie), stabilizacja osobowości, możliwość rozwijania własnych zainteresowań, potrzeba podkreślenia indywidualności w oparciu o oryginalność danej grupy. $\mathrm{Z}$ drugiej strony należy wymienić cechy subkultur wynikające z ponowoczesności, na które składają się: relatywizm wartości, odrzucenie tradycji na rzecz wolnego wyboru, podkreślenie autonomii jednostki - „różnicująca indywidualność” na tle grupy - heterogenizacja stylu, fragmentaryzm w obrębie przekonań, nastroje apolityczne, brak wyraźnych struktur i ideologii. Wspólnym celem subkultur i postsubkultur jest określenie własnej tożsamości w oparciu o tożsamość społeczną. Jest to więc próba identyfika-

\footnotetext{
Tamże, s. 269.

65 R. Geisler, Jednostka i spoteczeństwo..., s. 8.

66 Tamże, s. 67-68.
} 
cji (samokategoryzacji) dokonującej się poprzez zestawienie własnej indywidualności z poglądami danej subkultury. W odniesieniu do tej cechy ponowoczesność wyróżnia się mobilnością członków w obrębie różnych subkultur, co może świadczyć o wielości wyborów, wolności jednostki i autonomii przekonań. Elastyczność zachowań, giętkość przystosowawcza, gotowość do nabywania nowych umiejętności jest według Baumana dodatnią cechą osobowości ponowoczesnej: najlepiej wiedzie się osobnikom, których swobody ruchu nie krępuje precyzyjna specjalizacja, którzy nie maja zwyczaju koncentrowania uwagi zbyt dtugo na jednym przedmiocie, nie przywiazuja się nadmiernie do spraw, jakimi wypada im się zajać, i zachowuja dystans i wstrzemięźliwość emocjonalna wobec tego, czym się $w$ danym momencie zajmują ${ }^{67}$. Ujmowana w tych kategoriach mobilnosśc członków subkultur jest poszukiwaniem samego siebie, próbą dotarcia do własnej tożsamości, która nie jest nam dana, lecz zadana, jest więc zadaniem do wykonania, przed którym nie ma ucieczki ${ }^{68}$.

Na gruncie rosyjskim kreacja i funkcjonowanie współczesnych grup subkulturowych są poddawane tożsamym próbom opisu, jakie stosuje się w odniesieniu do nieformalnych zrzeszeń młodzieży na Zachodzie. Większość rosyjskich ruchów młodzieżowych była i jest tworzona na wzór zachodni, czego obecnie wzmożony przejaw odnosi się do roli i funkcji mass mediów. Niemniej jednak należy podkreślić specyfikę rosyjskiego kręgu kulturowego oraz kryzys świadomościowy wynikający z upadku Związku Radzieckiego i załamania się monolitycznej kultury. Tarnavskyi opisuje ów proces w następujący sposób: zamiast sterowanej i represyjnej kultury klarownych podziatów powstata przestrzeń, w której można zaobserwować ogromna ilość różnych stylów myślenia $i$ zachowañ ${ }^{69}$. W warunkach istnienia „społeczeństwa kryzysowego” młodzież rosyjska musiała zmagać się z wieloma problemami, które nierzadko wykraczały poza system pojęciowy wieku młodzieńczego i przerastały zdolności obronne tego okresu życia ludzkiego. Dlatego większość badaczy subkultur w Rosji podkreśla ich funkcję „ochronną” oraz pozytywne znaczenie dla zachowania psychologicznej równowagi młodych lu$\mathrm{dzi}^{70}$. Poszukiwanie własnej tożsamości w świecie zdominowanym przez chaos ułatwia wstąpienie do rówieśniczej grupy, w której uczestnictwo nie tylko pomaga w akceptacji własnego ,ja”, ale jest również próbą odpowiedzi na podstawowe pytanie każdego człowieka: kim jestem? Wielość wyborów nie ułatwia tego zadania ${ }^{71}$, jednak pluralizm jest wpisany w moralną odpowiedzialność współczesnego człowieka za swój los. Analizując dwudziestowieczną historię państwa rosyjskiego, należałoby skupić się na pozytywnych aspektach zaistniałej sytuacji i uwierzyć w człowieka jako jednostkę zdolną do podejmowania właściwych decyzji.

67 Z. Bauman, Dwa szkice o moralności ponowoczesnej, s. 16.

68 Tamże, s. 9.

69 V. Tarnavskyi, Dzieci swoich czasów..., s. 274.

70 Tamże, s. 275.

71 W Rosji odnotowuje się istnienie ponad 100 nieformalnych zrzeszeń młodzieży o charakterze kulturowym. Zob. V. Tarnavskyi, tamże, s. 130. 


\section{BIBLIOGRAFIA}

Балакирев Е., Сага о Системе, Вцадивосток 1999, [online] http://www.altruism.ru/sengine. cgi/5/24/17.

Bauman Z., Dwa szkice o moralności ponowoczesnej, Warszawa 1994, Biblioteka Kultury Wspótczesnej.

Bauman Z., Etyka ponowoczesna, przeł. J. Bauman, J. Tokarska-Bakir, Warszawa 1996.

Bauman Z., Ponowoczesność jako źródto cierpień, Warszawa 2000, Spojrzenia. Literatura Postmodernizmu.

Bauman Z., Socjologia, przeł. J. Łoziński, Poznań 1996.

Bauman Z., Spór o ponowoczesność, [w:] Ciato i przemoc wobliczu ponowoczesności, Toruń 1995, Wyktady Kopernikanskie w Humanistyce.

Bąk T., Wspótczesne uwarunkowania kreacji subkultur mtodzieżowych, Warszawa 2008.

Bokszański Z., Indywidualizm a zmiana spoteczna. Polacy wobec nowoczesności. Raport z badań, Warszawa 2007.

Bokszański Z., Tożsamości zbiorowe, Warszawa 2005.

Featherstone M., Postmodernizm i estetyzacja życia codziennego, przeł. P. Czapliński, J. Lang, [w:] Postmodernizm. Antologia przektadów, wybór i oprac. R. Nycz, Kraków 1997.

Filipiak M., Od subkultury do kultury alternatywnej. Wprowadzenie do subkultur mtodzieżwych, Lublin 1999.

Geisler R., Jednostka i spoteczeństwo w postmodernizmie, Częstochowa 1999.

Giddens A., Nowoczesność i tożsamość. "Ja" i spoteczeństwo w epoce późnej nowoczesności, przet. A. Szulżycka, Warszawa 2001, Biblioteka Socjologiczna.

Giddens A., Socjologia, przeł. A. Szulżycka, Warszawa 2004.

Jędrzejewski M., Od subkultur klasycznych do medialnych, „Remedium” 2002, nr 10, s. 2-3.

Mc Luhan M., Wybór pism, wybór J. Fuksiewicz, wstęp K.T. Toeplitz, przeł. K. Jakubowicz, Warszawa 1975.

Mead M., Kultura i tożsamość. Studium dystansu międzypokoleniowego, wstęp W. Adamski, przeł. J. Hołówka, Warszawa 1978, Biblioteka Socjologiczna.

Muggleton D., Wewnątrz subkultury. Ponowoczesne znaczenie stylu, przeł. A. Sadza, Kraków 2004, Cultura.

На путях постмодернизма. Сборник обзоров и рефератов, red. И. С. Анареева [i in.], Москва 1995.

Paleczny T., Kontestacja. Formy buntu we wspótczesnym spoteczeństwie, Kraków 1997, Prace Instytutu Polonijnego Uniwersytetu Jagiellońskiego.

Pęczak M., Maty stownik subkultur mtodzieżowych, Warszawa 1992, Wyktady Otwarte UMCS, 29.

Piotrowski P., Subkultury mtodzieżowe. Aspekty psychospoteczne, Warszawa 2003.

Prejs B., Bunt nie przemija. Bardzo podręczny stownik subkultur mtodzieżowych, KatowiceWarszawa 2004.

Sołżenicyn A., Rosja w zapaści, przeł. J. Zychowicz, Warszawa 1999.

Spontaniczna kultura mtodzieżowa: wybrane zjawiska, red. J. Wertenstein-Żuławski, M. Pęczak, Wrocław 1991. 
Strinati D., Postmodernizm i kultura popularna, [w:] tenże, Wprowadzenie do kultury popularnej, przeł. W. Burszta, Poznań 1998.

Subkultury mtodzieżowe wczoraj i dziś, red. M. Filipiak, Tyczyn 2001.

Щепанская Т. В., Молодежные сообщества, [w:] Современный городский фольклор, red. А. Ф. Белоусов [i in.], Москва 2003.

Щепанская Т. В., Система. Текстьь и традиции субкультурьь, Москва 2004.

Tarnavskyi V., Dzieci swoich czasów. Ruchy mtodzieżowe w Rosji a zmiany kulturowe po upadku ZSRR, Warszawa 2007.

Wobec kryzysu kultury. Z filozoficznych rozważań nad kulturą wspótczesną, red. L. Grudziński, Gdańsk 1993.

Dr Martyna KOWALSKA - doktor nauk humanistycznych, literaturoznawca, kulturoznawca, asystent w Katedrze Rosjoznawstwa UJ. Wybrane publikacje: Aleksander Sotżenicyn. Homo sovieticus i cztowiek sprawiedliwy, Toruń 2011; Trzy wymiary cierpienia. Cierpienie w literaturze rosyjskiej, „Slavia Orientalis” R. 55, 2006, nr 1; Wokót metafory i dostowności. Rozważania na marginesie powieści „Oddziat chorych na raka” Aleksandra Sotżenicyna, „Slavia Orientalis” R. 56, 2007, nr 1; Kobieta radziecka - wartościowa matka??, [w:] Ku antropologii rodziny, red. i wstęp L. Rożek, Częstochowa 2009, Prace Interdyscyplinarne, t. 7; Homo sovieticus - styl życia i zachowania nowego cztowieka w ZSRR, „Slavia Orientalis” R. 58, 2009, nr 3. Zainteresowania badawcze: kultura i literatura doby radzieckiej i postradzieckiej, rosyjska literatura emigracyjna, III fala emigracji rosyjskiej, ruch dysydencki w Rosji, współczesne życie kulturalne Rosji, kulturowe ruchy młodzieżowe w Rosji. 